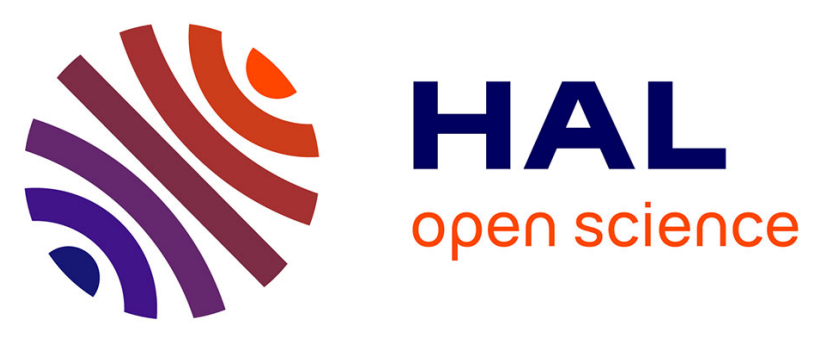

\title{
Differences in replication kinetics and cell tropism between neurovirulent and non-neurovirulent EHV1 strains during the acute phase of infection in horses
}

Annick C. Gryspeerdt, A.P. Vandekerckhove, B. Garré, F. Barbé, G.R. van de Walle, H.J. Nauwynck

\section{To cite this version:}

Annick C. Gryspeerdt, A.P. Vandekerckhove, B. Garré, F. Barbé, G.R. van de Walle, et al.. Differences in replication kinetics and cell tropism between neurovirulent and non-neurovirulent EHV1 strains during the acute phase of infection in horses. Veterinary Microbiology, 2010, 142 (3-4), pp.242. 10.1016/j.vetmic.2009.10.015 . hal-00587285

\section{HAL Id: hal-00587285 https://hal.science/hal-00587285}

Submitted on 20 Apr 2011

HAL is a multi-disciplinary open access archive for the deposit and dissemination of scientific research documents, whether they are published or not. The documents may come from teaching and research institutions in France or abroad, or from public or private research centers.
L'archive ouverte pluridisciplinaire HAL, est destinée au dépôt et à la diffusion de documents scientifiques de niveau recherche, publiés ou non, émanant des établissements d'enseignement et de recherche français ou étrangers, des laboratoires publics ou privés. 


\section{Accepted Manuscript}

Title: Differences in replication kinetics and cell tropism between neurovirulent and non-neurovirulent EHV1 strains during the acute phase of infection in horses

Authors: Annick C. Gryspeerdt, A.P. Vandekerckhove, B. Garré, F. Barbé, G.R. Van de Walle, H.J. Nauwynck

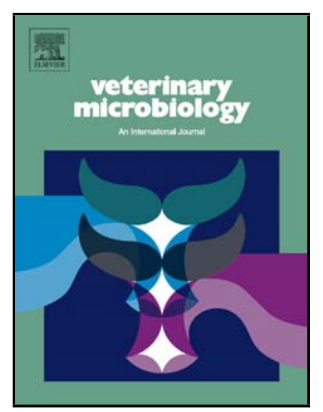

PII: S0378-1135(09)00535-5

DOI: doi:10.1016/j.vetmic.2009.10.015

Reference: VETMIC 4643

To appear in: $\quad$ VETMIC

Received date: $\quad$ 10-7-2009

Revised date: $\quad$ 13-10-2009

Accepted date: $\quad$ 16-10-2009

Please cite this article as: Gryspeerdt, A.C., Vandekerckhove, A.P., Garré, B., Barbé, F., Van de Walle, G.R., Nauwynck, H.J., Differences in replication kinetics and cell tropism between neurovirulent and non-neurovirulent EHV1 strains during the acute phase of infection in horses, Veterinary Microbiology (2008), doi:10.1016/j.vetmic.2009.10.015

This is a PDF file of an unedited manuscript that has been accepted for publication. As a service to our customers we are providing this early version of the manuscript. The manuscript will undergo copyediting, typesetting, and review of the resulting proof before it is published in its final form. Please note that during the production process errors may be discovered which could affect the content, and all legal disclaimers that apply to the journal pertain. 
1 Differences in replication kinetics and cell tropism between neurovirulent 2 and non-neurovirulent EHV1 strains during the acute phase of infection in horses Annick C. Gryspeerdt, A.P. Vandekerckhove, B. Garré, F. Barbé, G.R. Van de Walle ${ }^{* \#}$ and H.J. Nauwynck ${ }^{*}$

6

Laboratory of Virology, Department of Virology, Parasitology and Immunology, Faculty of Veterinary Medicine, Ghent University, Salisburylaan 133, 9820 Merelbeke, Belgium *shared senior authorship

$11 \quad$ Number of text pages: 30

12 Number of tables:1

13 Number of figures: 8

14 Shortened running title: In vivo differences of EHV1 strains replication

$16{ }^{\#}$ Corresponding author: Van de Walle Gerlinde

17 Laboratory of Virology, Department of Virology, Parasitology and Immunology

18 Faculty of Veterinary Medicine, Ghent University

19 Salisburylaan 133, 9820 Merelbeke, Belgium

20 Phone: 003292647375

$21 \quad$ Fax: 003292647495

22 E-mail: gerlinde.vandewalle@ugent.be 


\section{Abstract}

Equine herpesvirus 1 (EHV1) replicates in the respiratory tract of horses, after which infected leukocytes transport virus throughout the body, resulting in abortion or nervous system disorders. Two EHV1 strains circulate in the field: neurovirulent and non-neurovirulent. To investigate differences in replication in the upper respiratory tract (URT), an experimental inoculation study in ponies was performed with both strains. Two groups of six ponies, were inoculated intranasally with $10^{6.5} \mathrm{TCID}_{50}$ of either strain. Clinical signs, nasal shedding and viremia were evaluated. At early time points post inoculation (pi), one pony of each group was euthanized. Tissues were collected for titration and immunostainings. Number and size of EHV1-induced plaques were calculated, and individual EHV1-infected cells were quantified and characterized. Inoculation with either strain resulted in nasal shedding and replication in several tissues of the URT. Both strains replicated in a plaquewise manner in epithelium of the nasal mucosa, but replication in epithelium of the nasopharynx was largely limited to nonneurovirulent EHV1. Plaques were never able to cross the basement membrane, but individual infected cells were noticed in the connective tissue of all examined tissues for both strains. The total number of these cells however, was 3-7 times lower with non-neurovirulent EHV1 compared to neurovirulent EHV1. CD172a ${ }^{+}$cells and CD5+ lymphocytes were important target cells for both strains. Interestingly, in lymph nodes, B-lymphocytes were also important target cells for EHV1, irrespective of the strain. Viremia was detected very early pi and infected cells were mainly CD172 $\mathrm{a}^{+}$for both strains. In summary, these results are valuable for understanding EHV1 pathogenesis at the port of entry, the URT.

Keywords: EHV1, pathogenesis, strain differences, carrier cells 


\section{Introduction}

50 Infectious respiratory tract disease has been recognized as the cause of major health problems in horses. The most important respiratory pathogen is equine herpesvirus 1 (EHV1) and infections with this virus cause serious economic losses in the horse industry worldwide (Allen and Bryans, 1986; Ostlund, 1993; van Maanen, 2002). The upper respiratory tract is the first line of defence against respiratory pathogens and is also the primary replication site of EHV1, where it causes upper respiratory disorders (Kydd et al., 1994a, b). In addition, EHV1 can spread via infected blood leukocytes to internal organs, for example the pregnant uterus, causing symptoms such as abortion and neonatal foal death (Allen and Bryans, 1986). EHV1 can also reach the central nervous system, where replication in endothelial cells results in severe nervous system disorders with frequent fatal outcome. Neurological disease in horses caused by infection with certain isolates of EHV1 is a severe condition which is poorly understood (McCartan et al., 1995; Stierstorfer et al., 2002; van der Meulen et al., 2003a). The pathogenesis for developing this devastating condition is largely unknown and full protection against these secondary and severe symptoms can not be obtained by vaccination with the currently available vaccines (Heldens et al., 2001; Goodman et al., 2006; van der Meulen et al., 2007). Therefore, an improvement of the existing vaccines and/or the development of alternative strategies for the prevention and treatment of EHV1-induced infections are necessary. Importantly, this implies a firm notice about the pathogenesis of EHV1 during the acute phase of infection.

It has been suggested that distinct isolates of EHV1, differing in pathogenic capacity, circulate in the field. Nugent et al. (2006) indicated that a single nucleotide polymorphism (SNP) in the DNA polymerase is strongly associated with neurological versus nonneurological disease outbreaks. Studies in naturally infected horses with nervous system disorders have revealed a more robust cell-associated viremia in horses infected with 
neurovirulent isolates of EHV1, in contrast to horses infected with non-neurovirulent isolates (Allen and Breathnach, 2006). This was further confirmed by reverse genetic experiments of EHV1 strains with a sole mutation of the DNA polymerase SNP, where experimental inoculation with such strains altered neurologic disease in horses (Goodman et al., 2007; Van de Walle et al., 2009). Moreover, in vitro experiments with these strains revealed differences in leukocyte tropism which could explain the difference in clinical outcome (Goodman et al., 2007). Still, the exact identity of carrier cells susceptible to EHV1 infection and hereby responsible for dissemination of infectious virus to sites of secondary replication, is a matter of debate. Blood samples from experimentally infected ponies were collected and examined for the presence of neurovirulent EHV1 (Scott et al., 1983). Hereby, T-lymphocytes were found to be the most important cell fraction to harbor virus in vivo. However, no full characterization of these cells was performed. Different studies with in vitro EHV1-infected leukocytes have also been performed to determine the identity of these cells. Hereby, mainly monocytes were susceptible to infection with non-neurovirulent EHV1 (van der Meulen et al., 2000). After stimulation with mitogens, T-lymphocytes became more susceptible, followed by B-lymphocytes (van der Meulen et al., 2001). Despite these studies, information on possible differences between neurovirulent and non-neurovirulent EHV1 strains at the port of entry, and identity of carrier cells during viremia remains limited.

To investigate this, six Shetland ponies were experimentally inoculated with a neurovirulent EHV1 strain and six with a non-neurovirulent EHV1 strain. These animals were subsequently euthanized to collect different tissues of the upper respiratory tract. Tissues that were positive for EHV1 on titration were stained with markers for different cell types to determine and quantify the carrier cells of EHV1 in the upper respiratory tract. In addition, peripheral blood mononuclear cells (PBMC) were also collected to quantify and identify the infected cell type during cell-associated viremia. 
Materials and methods

101

Horses

Twelve male Shetland ponies, between the age of 6 months and 2 years, were used in this study. They were housed inside isolated stables. They were fed daily with a commercial, complete feed. Drinking water and hay were supplied ad libitum.

Prior to the experiment, ponies were monitored for 4 weeks. Rectal temperatures were measured daily and complement-dependent seroneutralization (SN)-tests and immunoperoxidase monolayer assays (IPMA) were performed weekly to determine EHVspecific antibody titers.

Virus and inoculation

Ponies were divided into two groups of 6. For the first group the Belgian EHV1 strain 03P37, isolated from the blood of a paralytic horse in 2003, was used for inoculation (Garre et al., 2009; van der Meulen et al., 2003a). The second group was inoculated with the Belgian strain 97P70, which was isolated from an aborted fetus (van der Meulen et al., 2006). The strains were typed in the DNA polymerase as $\mathrm{D}_{752}$ and $\mathrm{N}_{752}$ respectively in cooperation with

117 the Animal Health Trust in the United Kingdom (Nugent et al., 2006). Based on their origin

118 and genotyping, these strains will be referred as neurovirulent and non-neurovirulent in this 119 paper. Virus stocks used for inoculation were at the $6^{\text {th }}$ passage; 2 passages in rabbit kidney 120 cells (RK13) and 4 subsequent passages in equine embryonic lung cells (EEL). Both viruses 121 had virtually identical single-step growth properties in RK13 cells for intra- and extracellular virus yields at all tested time points post infection (data not shown). 
Ponies were inoculated oronasally with $20 \mathrm{ml}$ of a virus suspension containing $10^{6.5}$

124 tissue culture infectious dose ${ }_{50}\left(\mathrm{TCID}_{50}\right)$. Ten $\mathrm{ml}$ of the virus suspension was administered

125 intranasally $(5 \mathrm{ml}$ per nostril) using a thin probe and $10 \mathrm{ml}$ was inoculated orally with a

126 syringe. The virus titer was confirmed by titration of the inoculum.

Serological examination

For the seroneutralization (SN)-test, two-fold dilution series of the sera were prepared

in MEM. Fifty micro liter of these serial dilutions were incubated for 23 hours (h) at $37^{\circ} \mathrm{C}$

with a fixed number of infectious virus $\left(300 \mathrm{TCID}_{50}\right.$ of EHV1 strain Arabica in $\left.50 \mu \mathrm{l}\right)$.

Hereafter, $25 \mu \mathrm{l}$ of guinea pig complement was added. After $1 \mathrm{~h}$ of incubation, the mixture of serum, virus and complement was added to RK13 cells. Inoculated cultures were further incubated at $37^{\circ} \mathrm{C}$ in an atmosphere containing $5 \% \mathrm{CO}_{2}$. After 7 days of incubation, the cultures were analysed for the presence of cytopathic effect. The neutralization titer was calculated as the reciprocal of the highest dilution of the serum that was able to completely block EHV1 infection in RK13 cells.

For the immunoperoxidase monolayer assay (IPMA), RK13 cells were inoculated with $10^{3} \mathrm{TCID}_{50}$ of the EHV1 strain 97P70. After $28 \mathrm{~h}$, cells were washed, dried at $37^{\circ} \mathrm{C}$ for $1 \mathrm{~h}$ and stored at $-20^{\circ} \mathrm{C}$ until use. Plates were thawed and subsequently fixed with $4 \%$

141 paraformaldehyde and a solution containing $1 \%$ hydrogen peroxide in methanol. Following

142 extensive washing, serial 2-fold dilutions of the sera were added and cells were incubated for

$1431 \mathrm{~h}$ at $37^{\circ} \mathrm{C}$. Cells were incubated with peroxidase-labeled goat anti-horse antibodies (Jackson

144 ImmunoResearch Laboratories Inc., PA, USA) and after $1 \mathrm{~h}$, a substrate solution of 3-amino-

145 9-ethylcarbazole in $0.05 \mathrm{M}$ acetate buffer with $0.05 \%$ hydrogen was added to each well.

146 Following 20 minutes of incubation at $37^{\circ} \mathrm{C}$, substrate solution was replaced with acetate

147 buffer to block the enzymatic staining reaction. The IPMA titer was calculated as the 
148 reciprocal value of the highest serum dilution that induced visual staining of infected RK13

149 cells as determined by light microscopy.

Clinical examination

Horses were monitored daily for clinical signs by physical examination and measurement of rectal temperatures. Fever was defined as a rectal temperature $\geq 38.5^{\circ} \mathrm{C}$.

154 During clinical examination, nasal discharge (serous, mucous or purulent), lymph node swelling, tachypnea and coughing were evaluated. In addition, neurological exams were performed.

Virological examination

Nasopharyngeal mucus samples were taken daily until euthanasia. Immediately after collection, swabs were immersed in transport medium containing phosphate-buffered saline (PBS) supplemented with $10 \%$ fetal calf serum (FCS), $1000 \mathrm{U} / \mathrm{ml}$ penicillin, $1 \mathrm{mg} / \mathrm{ml}$ streptomycin and $0.5 \mathrm{mg} / \mathrm{ml}$ kanamycin. EHV1 in nasopharyngeal secretions was titrated on monolayers of RK13 cells, exactly as described previously (van der Meulen et al., 2003b).

167 slaughterhouse horses were collected and served as uninfected control samples. Per tissue,

168 two equal squares of $1 \mathrm{~cm}^{2}$ were collected from both left and right side of the head. From

169 each side, one square was frozen immediately with (immunofluorescence) or without (virus

170 titration) methylcellulose medium (Methocel ${ }^{\circledR} \mathrm{MC}$, Sigma-Aldrich, St. Louis, MO, USA) at -

$17170^{\circ} \mathrm{C}$. To determine viral replication, $20 \%$ suspensions of collected tissues were made and 
172 titrated on RK13 cells. Titers of infected tissues were determined after 7 days by means of

173 Reed and Muench's formula (Reed and Muench, 1938). of Veterinary Medicine.

Quantification and characterization of individual infected cells in tissues of the upper respiratory tract Immunofluorescent double stainings were used to quantify and characterize individual infected cells in tissues that were EHV1-positive after titration on RK13 cells. First, cryosections $(16 \mu \mathrm{m})$ were incubated with either monoclonal antibody (mAb) HT23A,

182 DH59B or 1.9/3.2 (VMRD Inc, Pullman, WA, USA) against CD5 (T-lymphocytes), CD172a

183 (cells from the monocyte lineage, CML) or IgM (B-lymphocytes) respectively, and subsequently incubated with Texas Red ${ }^{\circledR}$-labeled goat anti-mouse Abs (Molecular Probes, Eugene, OR, USA). Epithelial cells were identified based on the pancytokeratin marker MNF116 (Abcam, Cambridge, UK) and/or morphological features. Second, viral EHV1 proteins were stained by incubation with biotinylated polyclonal horse anti-EHV1 IgG (van

188 der Meulen et al., 2000), followed by streptavidin-FITC ${ }^{\circledR}$ (Molecular Probes, Eugene, OR, 189 USA). As controls, (i) stainings were performed on uninfected tissue and (ii) isotype control antibodies were included. All cryosections were analyzed using confocal microscopy (Leica TCS SP2 Laser scanning spectral confocal system, Leica Microsystems GmbH, Wetzlar,

192 Germany). Number and latitude of EHV1-induced plaques were calculated using the software

193 program ImageJ. Latitude was used to evaluate plaque size and therefore the degree of cell-to-

194 cell spread. In order to quantify infected cells in nasal septum, two main regions were taken

195 into account, on the one hand regions with and on the other hand regions without plaques in 196 the epithelium. These regions were then subdivided into three equal regions underneath the 
197

198

\section{Results}

epithelium: $\mathrm{A}, \mathrm{B}$ and $\mathrm{C}$ for regions with epithelial plaques and $\mathrm{D}, \mathrm{E}$ and $\mathrm{F}$ for regions without epithelial plaques (Fig 2A). For nasopharynx, tubal/nasopharyngeal tonsils and lymph nodes, subdivisions into different zones of functional importance were made (Fig 3A and 4A respectively). All regions were evaluated for the presence of plaques and/or individual infected cells. In addition, the total amount of infected cells (positive for staining with antiEHV1 Abs), equine immune cells (positive for staining with the mAbs against immune cell markers) and infected equine immune cells (double positive) were determined.

\section{Quantification and characterization of viremia}

Heparinized blood samples were taken daily until euthanasia and peripheral blood mononuclear cells (PBMC) were isolated by density centrifugation on Ficoll-Paque, according to manufacturer's instructions (Pharmacia Biotech AB, Uppsala, Sweden). To determine the magnitude of viremia, co-cultivation of PBMC on RK13 cells was performed as previously described (van der Meulen et al., 2003b). Remaining PBMC were resuspended in RPMI supplemented with 30\% FCS and 20\% Dimethyl Sulfoxide (DMSO) and frozen in liquid nitrogen for later examination to identify the nature of infected cells. Hereby, a double immunofluorescence staining was performed on acetone-fixed cell smears of PBMC. EHV1 expression was detected using a biotinylated polyclonal horse anti-EHV1 IgG (van der Meulen et al., 2003b), followed by streptavidin-FITC ${ }^{\circledR}$. The identity of infected cells was determined using the mAbs HT23A, DH59B or 1.9/3.2, as described above, followed by the incubation with Texas $\operatorname{Red}^{\circledR}$-labeled goat anti-mouse Abs. Samples were analyzed using confocal laser scanning microscopy. 


\section{EHV-status of the ponies before inoculation}

The inclusion criterium for ponies used in this study was a complete absence of EHVspecific antibodies by either SN-test $(<2)$ or IPMA $(<10)$. In addition, during the 4 -week observation period prior to the experiment, (i) no raise in temperature was noted, (ii) no EHVspecific antibodies were detected, and (iii) no virus was isolated from nasopharyngeal swabs. The use of naïve horses is an important tool to minimize variation in clinical and virological outcome due to differences in immunological status (Cornick et al., 1990; Heldens et al., 2001; Matsumura et al., 1996).

\section{Experimental inoculation with either strain induces fever and upper respiratory tract disease} in ponies

All ponies developed fever upon EHV1 inoculation with exception of the two ponies that were euthanized 24 hours post inoculation (hpi). Fever started at 48 hpi for the neurovirulent strain (5/5 animals) and at 36 (3/5 animals) or 48 hpi (2/5 animals) for the nonneurovirulent strain. High temperatures lasted for the complete observation period, with peak temperatures of $40.7^{\circ} \mathrm{C}$ for the neurovirulent strain and $40.1^{\circ} \mathrm{C}$ for the non-neurovirulent strain. Serous nasal discharge was noted after inoculation with both strains, starting at 1 day post inoculation (dpi). A transition to purulent nasal discharge was seen in both groups from 3 dpi. Breathing problems, consisting of tachypnea or coughing, were observed in two ponies of each group. Swelling of mandibular lymph nodes was observed in the majority of the ponies and occurred from 1 dpi in 2/6 animals inoculated with a neurovirulent strain and in 4/6 animals inoculated with a non-neurovirulent strain. Painful retropharyngeal lymph nodes were noted in 5/6 ponies inoculated with a non-neurovirulent strain, in contrast to only 2 ponies inoculated with a neurovirulent strain. None of the ponies showed neurological signs, irrespective of the strain used for inoculation. The latter is not too unexpected, as the 
incubation period of EHV1-induced neurological disorders is normally 6 to 10 days (Edington

248 et al., 1986; Jackson et al., 1977; Mumford and Edington, 1980). Moreover, nervous system

249 disorders have been described to occur more frequently in older horses and certain breeds

250 (Garre et al., 2009; Goehring et al., 2006; Greenwood and Simson, 1980; Jackson et al., 1977;

251 McCartan et al., 1995).

Experimental inoculation with either strain results in nasal shedding and viral replication in

the upper respiratory tract, but differences were observed in the preferential epithelial replication site between strains

When evaluating nasal shedding, by titrations of nasal swab samples, five out of six

ponies inoculated with the neurovirulent strain shed virus from 1 dpi, with a peak excretion at

2 dpi (Fig 1). Nasal shedding then slowly decreased until 7 dpi. For the non-neurovirulent strain, 6 out of 6 ponies shed virus at 1 dpi, reaching a peak at 2 dpi with remaining high titers until 7 dpi (Fig 1).

Next, different tissue samples were collected from the upper respiratory tract of one pony per group per day for viral titrations. Virus could not be isolated from any tissue at $1 \mathrm{dpi}$ for the neurovirulent strain, but was found in the nasopharynx of ponies inoculated with the non-neurovirulent strain (Fig 2). From 2 dpi, virus was mainly recovered from different parts of the nasal septum and the nasopharynx for both strains (Fig 2). Septum and nasopharynx remained positive for EHV1 until $7 \mathrm{dpi}$, with the exception of day 5 for the neurovirulent strain where no virus was detected in the nasopharynx (Fig 2) and day 4 for the nonneurovirulent strain where the distal nasal septum was negative (Fig 2). No difference in virus titers could be noticed in the nasal septum, but titers found in the nasopharynx seemed to be higher after inoculation with the non-neurovirulent strain of EHV1 compared to the 
should be careful to draw any conclusions based on these results. Virus was also found in lymphoid tissues such as the tubal and nasopharyngeal tonsils and mandibular lymph nodes (Fig 2). In general, titers found in tubal and nasopharyngeal tonsils (Fig 2) were higher for the non-neurovirulent strain. Titers detected in mandibular lymph nodes started rising from 3 dpi (neurovirulent strain) or $4 \mathrm{dpi}$ (non-neurovirulent strain), and at 7dpi, mandibular lymph nodes were positive for the non-neurovirulent strain only (Fig 2). EHV1 could also be isolated for both strains at different time points pi from the ethmoid, the cranial part of the trachea and 3 different tonsils (data not shown).

Finally, replication of EHV1 was evaluated in the epithelium of different tissues of the upper respiratory tract by immunofluorescence. Hereby, EHV1-induced plaques were analyzed and plaque latitudes measured. In the epithelium of the entire nasal septum, EHV1induced plaques were seen at different time points pi for both strains (Fig 3A). These plaques were defined as groups of infected epithelial cells. Since results for proximal, intermedial and distal nasal septum were virtually identical, only results for the intermedial nasal septum are shown. Plaques were not present in the epithelium at 0 and 1 dpi (Fig 3A). However, individual infected cells were observed at $1 \mathrm{dpi}$, which were identified as CD172a ${ }^{+}$cells, as determined by the marker DH59B, or epithelial cells, as determined by the pancytokeratin marker (data not shown). For the neurovirulent strain, EHV1-induced plaques were observed in the epithelium of the nasal mucosa starting from 2 till 7 dpi (Fig 3A). At 2, 3 and 4 dpi, these plaques consisted of epithelial cells and rarely one or two CD172a ${ }^{+}$cells. From 5 dpi, EHV1-positive cells became separated from the basement membrane (BM) and these cells were exclusively positive for the DH59B marker which identifies cells of the monocytic lineage (CML) (Fig 3A). This observation was not seen in ponies inoculated with a nonneurovirulent strain. There, plaques were present in the epithelium of the nasal mucosa and nasopharynx from 2 till 7 dpi (Fig 3A \& B). These plaques consisted of epithelial cells and 
rarely some CD172a ${ }^{+}$cells, but no separation of EHV1-positive cells was observed (Fig 3A). No differences were observed in both number (data not shown) and size (Fig 3A) of EHV1induced plaques in the intermedial nasal mucosa at different time points pi for both strains. In the epithelium of the nasopharynx, plaques could be found for the non-neurovirulent strain from 2 till 7 dpi, with the exception of 4 dpi (Fig 3B). In contrast, no plaques were found for the neurovirulent strain in the nasopharyngeal epithelium, with the exception of one small plaque at 3 dpi (Fig 3B). Interestingly, plaques were not able to cross the BM at any time point pi, but single EHV1-infected cells could be noticed in the connective tissue from $1 \mathrm{dpi}$.

Taken together, these results show that EHV1 infection results in nasal shedding and replication in several tissues of the upper respiratory tract, irrespective of its neuropathogenic potential. However, whereas both types of EHV1 replicate equally in the epithelium of the nasal mucosa, replication in the nasopharynx was limited to non-neurovirulent EHV1.

Neurovirulent EHV1 uses mainly CD172a $a^{+}$cells as carrier cells in tissues of the upper respiratory tract, whereas non-neurovirulent EHV1 shows a tropism for both $\mathrm{CD} 172 \mathrm{a}^{+}$cells and $\mathrm{CD}^{+}$cells

As mentioned before, EHV1-induced plaques never crossed the BM, irrespective of the strain used. However, individual infected cells were observed in the underlying connective tissue and the total number was 3-7 times lower with non-neurovirulent EHV1 compared to neurovirulent EHV1. To identify the nature of these cells, cryosections of tissues were made and double immunofluorescence stainings were performed.

Nasal septum. In the connective tissue of the nasal septum, no differences were observed in the total amount of infected cells present beneath epithelium with plaques or without plaques, with the exception of 5 and 7 dpi for the neurovirulent strain, where a 
marked increase in infected cells was observed in region A (Fig 4). Such increase was not

322 seen in the regions located underneath epithelium without plaques (Fig 4).

Nasopharynx. EHV1-infected cells were present in the connective tissue of the nasopharynx from 1 till $7 \mathrm{dpi}$, irrespective of the strain used, however, the localization of these cells appeared to be strain-dependent (Fig 5). Whereas for the neurovirulent strain, single infected cells were mainly found in epithelium (region A) and connective tissue (region B), single infected cells were located in connective tissue (region B) and lymphocyte aggregates (region C) for the non-neurovirulent strain (Fig 5).

Tubal and nasopharyngeal tonsils. For both EHV1 strains, single infected cells were observed starting from 2 dpi (Fig 6). They were mostly present in the connective tissue underneath the epithelium (region B) and lymphocyte aggregates (region C, Fig 6), but single infected cells could also be observed in epithelium/fundus (region A), deeper connective tissue (region D), blood vessels (region E) and glands (region F) (Fig 6).

Mandibular lymph nodes. For the neurovirulent strain, most of the infected cells were found in the marginal sinus of the mandibular lymph nodes (region C, Fig 7). Their number increased until 4 dpi and rapidly decreased afterwards, with rarely any infected cells 337 left at $7 \mathrm{dpi}$. Furthermore, infected cells were also observed in the capsule and trabecula 338 (region A), the medulla (region F) and in fewer amounts in vessels of the capsule and the 339 cortical nodules (regions B and D, Fig 7). In these regions a peak number of infected cells 340 was observed at 4 and 5 dpi (Fig 7). For the non-neurovirulent strain, single cells were only 341 found from 4 till $7 \mathrm{dpi}$ and were mostly found in the marginal sinus (region C) and medulla 342 (region F) (Fig 7). Immunofluorescence stainings, using mAbs against immune cell surface markers

344 showed that in all tissues of the upper respiratory tract, infected cells were largely CD172 $\mathrm{a}^{+}$ 345 CML, followed by a slightly lower amount of infected $\mathrm{CD}^{+}$lymphocytes when the 
neurovirulent EHV1 strain was used for inoculation (Table I). These results were very similar

to what was observed with the non-neurovirulent strain, although a more substantial amount

of infected $\mathrm{CD}^{+}$lymphocytes was observed in these different tissues of the upper respiratory

tract (Table I). $\operatorname{IgM}^{+}$lymphocytes were always present, but rarely infected with the exception

of the mandibular (Table I) and retropharyngeal (data not shown) lymph nodes, were these cells were an important target cell type for both strains.

Ponies became viremic upon experimental inoculation with either strain, and CD172a $a^{+}$cells

were the most important carrier cells in the blood

Transmission of EHV1 from PBMC to susceptible RK13 cells, as determined by cocultivation, was observed in 5 out of 6 ponies upon experimental inoculation with neurovirulent EHV1 (Fig 8). No differences in the amount of infected PBMC was noted, except for one pony, which showed a higher level of viremia at 4 and 5 dpi compared to the other infected ponies (Fig 8). For the non-neurovirulent strain, viremia was observed in all six

360 infected ponies, with no differences in magnitude for the first 4 dpi (Fig A). However, at day 3615 and 7 pi, the non-neurovirulent strain seemed to retain a higher viremia level then the 362 neurovirulent strain, but due to the low amount of animals left at those days, no conclusions 363 could be drawn (Fig 8).

364 In addition, around $2 \times 10^{7}$ mononuclear cells for each strain were analyzed by 365 confocal microscopy to detect infected cells and further characterize their nature. These cells 366 were a mixture of PBMC from three ponies collected at 2, 3 and 4 dpi. For the neurovirulent 367 strain, fourteen EHV1-infected cells were found and eleven were characterized as CD172a ${ }^{+}$ 368 cells (78.5\%), whereas three were $\mathrm{CD}^{+}$(21.5\%). No infected B-lymphocytes were found. For 369 the non-neurovirulent strain, nine EHV1-infected cells were identified, consisting of seven 
$370 \mathrm{CD} 172 \mathrm{a}^{+}$cells $(77.8 \%)$, one $\mathrm{CD}^{+} \mathrm{T}$-lymphocyte $(11.0 \%)$ and one cell remained unidentified.

371 Also here, no infected B-lymphocytes were found.

372 These data indicate that $\mathrm{CD} 172 \mathrm{a}^{+}$cells appear to be the main target cell during EHV1-

373 induced viremia, irrespective of the neuropathogenicity of EHV1.

374 


\section{Discussion}

Despite several studies conducted on the pathogenesis of equine herpesvirus type 1

377 (EHV1), it still remains unclear how this virus invades the tissues of the upper respiratory tract and invades the deeper tissues to initiate a cell-associated viremia. Furthermore, two strains of EHV1 circulate in the field, namely non-neurovirulent and neurovirulent strains, the latter causing neurological disease, a severe condition which is poorly understood. In the present study, we used the two strains of EHV1 to gain more insight into the pathogenesis of these strains during the acute phase of infection in the upper respiratory tract in vivo. To this end, Shetland ponies were experimentally inoculated with either a non-neurovirulent or a neurovirulent EHV1 strain and upon euthanasia, several tissues from the upper respiratory tract were collected and analyzed.

It was found that EHV1 has different approaches to successfully establish an infection in the upper respiratory tract. Firstly, we observed that EHV1, irrespective of the strain, can replicate in the epithelium of the nasal septum and/or nasopharynx by means of virus-induced plaques. This replication appears to occur in a restricted way, as no increase in number or size of plaques was observed over time. In addition, a repulsion of EHV1-induced plaques was observed from 5 dpi onwards for the neurovirulent strain, and a decrease in plaque latitude was seen for the non-neurovirulent strain starting at day 3 pi. This reduction in replication might be attributed to the production of interferon (IFN), as (i) the presence of interferon in nasal secretions after experimental inoculation of horses with EHV1 has previously been described and (ii) peak concentrations of IFN- $\alpha$ were noted at day 4 and day 7 pi (Bridges and 396 Edington, 1986; Edington et al., 1989). In the present study, IFN- $\alpha$ was also found in nasal swabs of experimentally infected ponies (data not shown), which further points towards the importance of IFN to limit EHV1 replication in the epithelium of the upper respiratory tract. 
manner in the epithelium of the nasopharynx, no plaques could be observed at any time point pi in the nasopharynx after inoculation with the neurovirulent strain. As the epithelial structure of both tissues is identical, with the exception of the presence of lymphoid aggregates in the nasopharynx, the reason for this observation remains elusive. Another interesting observation for both EHV1 strains was that we were unable to observe EHV1infected plaques under the basement membrane (BM) at any time point pi, indicating that EHV1 does not reach the underlying tissue by breaking down the BM. This is in striking contrast to previous findings with another and closely related alphaherpesvirus, pseudorabies virus (PRV), which has been shown to cross the BM in a plaque wise manner between 12 and 24 hpi in a porcine respiratory explant model (Glorieux et al., 2009). This indicates that different alphaherpesviruses may use different mechanisms to invade the underlying connective tissue. Indeed, whereas PRV was shown to break down the BM and replicates further in the underlying tissue in a plaquewise manner, our study with EHV1 demonstrated only single infected cells below the BM. This is in agreement with previous studies on EHV1, where the presence of single infected cells in tissues of the upper respiratory tract has been reported (Edington et al., 1986; Kydd et al., 1994). We could further demonstrate that these infected cells in the underlying tissue were immune cells (as discussed in more detail below), which makes it tempting to speculate that immune cells in the epithelium become infected with EHV1 and are responsible for transporting the virus to deeper connective tissue. Indeed, we did found EHV1-infected cells in the epithelium of nasal septum and/or nasopharynx, which were further characterized to belong to the monocytic lineage (CML) by using the cell surface maker CD172a. Not only differences concerning the identity of the EHV1-infected immune cells present in the underlying tissues were noticed between both strains, moreover, differences concerning there localization were also observed. When analyzing the identity of the single EHV1-infected cells in the connective tissue of nasal septum and nasopharynx, 
several differences could be observed between the two EHV1 strains. Firstly, the total number of infected cells in the nasal septum was 10 to 20 times higher for the neurovirulent strain compared to the non-neurovirulent strain. Secondly, while individual infected cells in the nasopharynx were mainly present in the connective tissue upon neurovirulent EHV1 inoculation, individual cells infected with the non-neurovirulent EHV1 seemed to migrate deeper into the lymphoid follicles of the nasopharynx in a time wise manner. Thirdly, CD172 $\mathrm{a}^{+} \mathrm{CML}$ were the most important carrier cells for both neurovirulent and nonneurovirulent EHV1, although these cells seemed to be more important for the neurovirulent strain. In addition, both strains were able to infect $\mathrm{CD}^{+} \mathrm{T}$-lymphocytes, with a higher amount of infected cells for the non-neurovirulent strain (Table I). When analyzing the data on the identity of infected cells in lymphoid tissues of the upper respiratory tract, we again observed that the most prominent target cells for EHV1 were CD172a ${ }^{+} \mathrm{CML}$, irrespective of the strain used. This is in line with previous studies, where EHV1-infected macrophages and lymphoblasts were detected in lymph nodes after inoculation with EHV1 isolates from both an aborted fetus and a paralyzed mare (Patel et al., 1982). Moreover, another EHV1 experimental inoculation study showed that lymphocytes, monocytes, macrophages and plasma cells in interstitium and lymph nodes all expressed EHV1 antigens, as determined by immunohistochemical staining using anti-EHV1 polyclonal Abs (Kydd et al., 1994). In the present study, the majority of EHV1-positive cells was found in the marginal sinus of lymph nodes. At those sites, transport is possible to extra follicular interdigitating cells in the lymph node where both mature and virgin lymphocytes have access to antigen, hereby initiating humoral immune responses (Tew et al., 1990). Surprisingly, and in contrast to what was observed in nasal septum and nasopharynx, $\operatorname{IgM}^{+}$B-lymphocytes were also an important target cell for EHV1. In vitro it has been previously shown that a 6- to 14-fold increase of EHV1-infected peripheral blood mononuclear cells (PBMC) could be obtained after in vitro 
stimulation with proliferating drugs such as pokeweed mitogen (PWM), concanavalin A

451 (ConA), phytohaemagglutinin (PHA), or ionomycin and phorbol dibutyrate (IONO/PDB)

452 (van der Meulen et al., 2001). Together with the fact that B-lymphocytes are known to 453 undergo extensive proliferation in lymphoid follicles (Fu and Chaplin, 1999), we would like 454 to reason that the elevated percentage of EHV1-infected B-lymphocytes observed in 455 lymphoid tissues, is due to the proliferation stage of these immune cells.

The onset of a cell-associated viremia could be detected as early as one day after experimental inoculation with EHV1, indicating that EHV1-infected cells can enter the blood stream very rapidly. Moreover, we identified these EHV1-positive cells as mainly CD172a ${ }^{+}$

CML. Despite the fact that only 14 infected cells were found, we strongly feel that this low number is of relevance, as it is known that EHV1-induced viremia is generally very low with numbers ranging from 1 to 10 positive cells/ $/ .8$ x $10^{7}$ PBMC (van der Meulen et al., 2006). Combining the results on the identity of EHV1-infected cells in the connective tissues of the primary port of entry, the upper respiratory tract, with the results on the identity of the EHV1infected cells in the blood, we would like to hypothesize that the CD172a ${ }^{+}$cells we observed could be dendritic cells (DCs). The reasoning behind such hypothesis is as follows. The marker DH59B that was used in the present study to identify CD172a ${ }^{+}$cells is a pan granulocyte/monocyte marker which has been used in several studies as a DC marker (Ahn et al., 2002; Tumas et al., 1994). In addition, there is evidence indicating that local tissue DCs are able to re-enter the bloodstream, which might facilitate the spread of pathogens from 470 tissue to tissue, carried by DCs serving as Trojan horses (Randolph et al., 2008). Finally, DCs 471 have been shown to play an important role during the pathogenesis of alphaherpesviruses in general (Bosnjak et al., 2005; Novak and Peng, 2005; Pollara et al., 2005), and for EHV1 in specific, both murine and equine blood-derived DCs are susceptible to EHV1 in vitro (Siedek

474 et al., 1999; Steinbach et al., 1998). Unfortunately, little is known about equine DCs in 
general and mucosal DCs in specific in this species, and more research is needed to elucidate

476 the role of DCs in EHV1 infection and/or other viral infections in equines. Regardless, the

477 results presented here are in striking contrast to another in vivo study, where mainly blood T-

478 lymphocytes were found to harbor EHV1 (Scott et al., 1983). However, in the latter study, 479 leukocyte populations were solely separated by glass-bead columns and no direct 480 characterization was performed. A possible explanation for the discrepancy between cell 481 types infected during cell-associated viremia could be the strain used. In a previous study an 482 American strain, isolated from an aborted fetus, was used (Scott et al., 1983) whereas in the 483 present study, we used two Belgian EHV1 strains. Surprisingly, we observed CD172a ${ }^{+}$cells 484 as the main carrier cell type for both the neurovirulent and the non-neurovirulent strain, 485 indicating that the EHV1 strain does not seem to correlate with a difference in cell tropism 486 during viremia. This is again in contrast to another study, where a difference in leukocyte tropism between neuro- and non-neurovirulent EHV1 strains has been demonstrated (Goodman et al., 2007). Hereby it was observed that the EHV1 strain Ab4, which has the neuropathogenic genotype, mainly infected $\mathrm{CD} 4^{+}$lymphocytes, whereas mutating this strain into the non-neuropathogenic genotype resulted in a preferential infection of monocytes and 491 B-cells. However, these experiments were performed with in vitro infected PBMC, which most likely explains the discrepancy with our in vivo data.

\section{Conclusion}

Based on all the observations presented in this study, we would like to propose 496 following model on the pathogenesis of different EHV1 strains in the upper respiratory tract. 497 Upon infection, EHV1 replication in epithelial cells of the nasal septum, and nasopharynx for 498 the non-neurovirulent strain, results in a productive infection with plaque formation and nasal 499 virus shedding. This nasal shedding allows for transmission of virus to susceptible contact 
animals and ensures that EHV1 can persist in the equine population. This productive infection

501 in epithelial cells, however, is self-limiting, most likely because of IFN- $\alpha$ production. In addition, EHV1 seems to cross the BM through the help of $\mathrm{CD} 172 \mathrm{a}^{+}$carrier cells, probably mucosal dendritic cells. We postulate that these carrier cells which become infected with

504 EHV1 can transport the virus across the basement membranes and through connective tissues 505 in the direction of vascular endothelial cells on the one hand and lymphatic epithelium on the 506 other hand. As a result, a cell-associated viremia is originated, together with a migration of 507 infected immune cells to local lymph nodes, hereby initiating the start of a specific immune response. Although not observed in this study, the higher potential of the neurovirulent strain to infect large amounts of carrier cells, could lead to a prolonged viremia, with a higher risk 510 of developing nervous system disorders.

511 Despite the fact that only a limited number of animals could be included in this experiment, 512 we still feel that this paper revealed important new insights about the pathogenesis of 513 neurovirulent and non-neurovirulent strains in the acute phase of infection in horses.

\section{Acknowledgements}

This research was supported by the Institute for the promotion of Innovation through Science and Technology in Flanders (IWT-Vlaanderen). The authors like to thank C. Boone and N. Monteiro for titrations, and C. Bracke for isolation of PBMC and performing SN-tests.

\section{Conflict of interest}

None of the authors of this paper has a financial or personal relationship with other people or organisations that could inappropriately influence or bias the content of the paper.

\section{References}


Ahn, J.S., Konno, A., Gebe, J.A., Aruffo, A., Hamilton, M.J., Park, Y.H., Davis, W.C., 2002, Scavenger receptor cysteine-rich domains 9 and 11 of $\mathrm{WC} 1$ are receptors for the WC1 counter receptor. J Leukoc Biol 72, 382-390.

Allen, G.P., Breathnach, C.C., 2006, Quantification by real-time PCR of the magnitude and duration of leucocyte-associated viraemia in horses infected with neuropathogenic vs. non-neuropathogenic strains of EHV-1. Equine Vet J 38, 252-257.

Allen, G.P., Bryans, J.T., 1986, Molecular epizootiology, pathogenesis, and prophylaxis of equine herpesvirus-1 infections. Prog Vet Microbiol Immunol 2, 78-144.

Bosnjak, L., Jones, C.A., Abendroth, A., Cunningham, A.L., 2005, Dendritic cell biology in herpesvirus infections. Viral Immunol 18, 419-433.

Bridges, C.G., Edington, N., 1986, Innate immunity during Equid herpesvirus 1 (EHV-1) infection. Clin Exp Immunol 65, 172-181.

Cornick, J., Martens, J., Martens, R., Crandell, R., McConnell, S., Kit, S., 1990, Safety and efficacy of a thymidine kinase negative equine herpesvirus-1 vaccine in young horses. Can J Vet Res 54, 260-266.

Edington, N., Bridges, C.G., Griffiths, L., 1989, Equine interferons following exposure to equid herpesvirus-1 or -4. J Interferon Res 9, 389-392.

Edington, N., Bridges, C.G., Patel, J.R., 1986, Endothelial cell infection and thrombosis in paralysis caused by equid herpesvirus-1: equine stroke. Arch Virol 90, 111-124.

Fu, Y.X., Chaplin, D.D., 1999, Development and maturation of secondary lymphoid tissues. Annu Rev Immunol 17, 399-433.

Garre, B., Gryspeerdt, A., Croubels, S., De Backer, P., Nauwynck, H., 2009, Evaluation of orally administered valacyclovir in experimentally EHV1-infected ponies. Vet Microbiol 135, 214-221. 
Glorieux, S., Favoreel, H.W., Meesen, G., de Vos, W., Van den Broeck, W., Nauwynck, H.J., 2009, Different replication characteristics of historical pseudorabies virus strains in porcine respiratory nasal mucosa explants. Vet Microbiol 136, 341-346.

Goehring, L.S., van Winden, S.C., van Maanen, C., Sloet van Oldruitenborgh-Oosterbaan, M.M., 2006, Equine herpesvirus type 1-associated myeloencephalopathy in The Netherlands: a four-year retrospective study (1999-2003). J Vet Intern Med 20, 601607.

Goodman, L.B., Loregian, A., Perkins, G.A., Nugent, J., Buckles, E.L., Mercorelli, B., Kydd, J.H., Palu, G., Smith, K.C., Osterrieder, N., Davis-Poynter, N., 2007, A point mutation in a herpesvirus polymerase determines neuropathogenicity. PLoS Pathog 3, 15831592.

Greenwood, R.E., Simson, A.R., 1980, Clinical report of a paralytic syndrome affecting stallions, mares and foals on a thoroughbred studfarm. Equine Vet J 12, 113-117.

Heldens, J.G., Hannant, D., Cullinane, A.A., Prendergast, M.J., Mumford, J.A., Nelly, M., Kydd, J.H., Weststrate, M.W., van den Hoven, R., 2001, Clinical and virological evaluation of the efficacy of an inactivated EHV1 and EHV4 whole virus vaccine (Duvaxyn EHV1,4). Vaccination/challenge experiments in foals and pregnant mares. Vaccine 19, 4307-4317.

Jackson, T.A., Osburn, B.I., Cordy, D.R., Kendrick, J.W., 1977, Equine herpesvirus 1 infection of horses: studies on the experimentally induced neurologic disease. Am J Vet Res 38, 709-719.

Kydd, J.H., Smith, K.C., Hannant, D., Livesay, G.J., Mumford, J.A., 1994, Distribution of equid herpesvirus-1 (EHV-1) in the respiratory tract of ponies: implications for vaccination strategies. Equine Vet J 26, 466-469. 
Matsumura, T., O'Callaghan, D.J., Kondo, T., Kamada, M., 1996, Lack of virulence of the murine fibroblast adapted strain, Kentucky A (KyA), of equine herpesvirus type 1 (EHV-1) in young horses. Vet Microbiol 48, 353-365.

McCartan, C.G., Russell, M.M., Wood, J.L., Mumford, J.A., 1995, Clinical, serological and virological characteristics of an outbreak of paresis and neonatal foal disease due to equine herpesvirus-1 on a stud farm. Vet Rec 136, 7-12.

Mumford, J.A., Edington, N., 1980, EHV1 and equine paresis. Vet Rec 106, 277.

Novak, N., Peng, W.M., 2005, Dancing with the enemy: the interplay of herpes simplex virus with dendritic cells. Clin Exp Immunol 142, 405-410.

Nugent, J., Birch-Machin, I., Smith, K.C., Mumford, J.A., Swann, Z., Newton, J.R., Bowden, R.J., Allen, G.P., Davis-Poynter, N., 2006, Analysis of equid herpesvirus 1 strain variation reveals a point mutation of the DNA polymerase strongly associated with neuropathogenic versus nonneuropathogenic disease outbreaks. J Virol 80, 4047-4060.

Ostlund, E.N., 1993, The equine herpesviruses. Vet Clin North Am Equine Pract 9, 283-294.

Patel, J.R., Edington, N., Mumford, J.A., 1982, Variation in cellular tropism between isolates of equine herpesvirus-1 in foals. Arch Virol 74, 41-51.

Pollara, G., Kwan, A., Newton, P.J., Handley, M.E., Chain, B.M., Katz, D.R., 2005, Dendritic cells in viral pathogenesis: protective or defective? Int J Exp Pathol 86, 187-204.

Randolph, G.J., Ochando, J., Partida-Sanchez, S., 2008, Migration of dendritic cell subsets and their precursors. Annu Rev Immunol 26, 293-316.

Reed, L.J., Muench, H., 1938, A simple method of estimating fifty per cent endpoints. Am J Hyg 27, 493-497.

Scott, J.C., Dutta, S.K., Myrup, A.C., 1983, In vivo harboring of equine herpesvirus-1 in leukocyte populations and subpopulations and their quantitation from experimentally infected ponies. Am J Vet Res 44, 1344-1348. 
Siedek, E.M., Whelan, M., Edington, N., Hamblin, A., 1999, Equine herpesvirus type 1 infects dendritic cells in vitro: stimulation of $\mathrm{T}$ lymphocyte proliferation and cytotoxicity by infected dendritic cells. Vet Immunol Immunopathol 67, 17-32.

Steinbach, F., Borchers, K., Ricciardi-Castagnoli, P., Ludwig, H., Stingl, G., Elbe-Burger, A., 1998, Dendritic cells presenting equine herpesvirus-1 antigens induce protective antiviral immunity. J Gen Virol 79, 3005-3014.

Stierstorfer, B., Eichhorn, W., Schmahl, W., Brandmuller, C., Kaaden, O.R., Neubauer, A., 2002, Equine herpesvirus type 1 (EHV-1) myeloencephalopathy: a case report. J Vet Med B Infect Dis Vet Public Health 49, 37-41.

Tew, J.G., Kosco, M.H., Burton, G.F., Szakal, A.K., 1990, Follicular dendritic cells as accessory cells. Immunol Rev 117, 185-211.

Tumas, D.B., Brassfield, A.L., Travenor, A.S., Hines, M.T., Davis, W.C., McGuire, T.C., 1994, Monoclonal antibodies to the equine CD2 T-lymphocyte marker, to a pangranulocyte monocyte marker and to a unique pan-B lymphocyte marker. Immunobiology 192, 48-64.

Van de Walle, G.R., Goupil, R., Wishon, C., Damiani, A., Perkins, G.A., Osterrieder, N., 2009, A Single-Nucleotide Polymorphism in a Herpesvirus DNA Polymerase Is Sufficient to Cause Lethal Neurological disease. J Infect Dis 200, 20-25.

van der Meulen, K., Caij, B., Pensaert, M., Nauwynck, H., 2006, Absence of viral envelope proteins in equine herpesvirus 1-infected blood mononuclear cells during cellassociated viremia. Vet Microbiol 113, 265-273.

van der Meulen, K., Vercauteren, G., Nauwynck, H., Pensaert, M., 2003a, A local epidemic of equine herpesvirus 1-induced neurological disorders in Belgium. Vlaams Diergen Tijds 72, 366-372. 
van der Meulen, K.M., Nauwynck, H.J., Buddaert, W., Pensaert, M.B., 2000, Replication of equine herpesvirus type 1 in freshly isolated equine peripheral blood mononuclear cells and changes in susceptibility following mitogen stimulation. J Gen Virol 81, 2125.

van der Meulen, K.M., Nauwynck, H.J., Pensaert, M.B., 2001, Mitogen stimulation favours replication of equine herpesvirus-1 in equine blood mononuclear cells by inducing cell proliferation and formation of close intercellular contacts. J Gen Virol 82, 1951-1957.

van der Meulen, K.M., Nauwynck, H.J., Pensaert, M.B., 2003b, Absence of viral antigens on the surface of equine herpesvirus-1-infected peripheral blood mononuclear cells: a strategy to avoid complement-mediated lysis. J Gen Virol 84, 93-97.

van Maanen, C., 2002, Equine herpesvirus 1 and 4 infections: an update. Vet Q 24, 58-78.

\section{Figure legends}

Figure 1. Nasal viral shedding. Ponies were inoculated with a neurovirulent or a nonneurovirulent strain of EHV1. At 0, 1, 2, 3, 4, 5 and 7 days post inoculation (dpi), nasopharyngeal swabs were collected and titrated as described in material and methods.

Figure 2. Viral replication in different tissues of the upper respiratory tract. Ponies were inoculated with either neurovirulent or non-neurovirulent EHV1 and euthanized at 0, 1, 2, 3, 4, 5 and 7 days post inoculation (dpi). Different tissues were collected and titrated as described in materials and methods.

\section{Figure 3. Plaque formation in epithelium of intermedial nasal septum and nasopharynx.}

Ponies were inoculated with either neurovirulent or non-neurovirulent EHV1 and euthanized 
at $0,1,2,3,4,5$ and 7 days post inoculation (dpi). Tissues of the intermedial part of the nasal septum (A) and nasopharynx (B) were collected and latitude of plaques were determined. For each tissue, ten consecutive sections were made and the total number of individual plaques was determined. This number is presented above the relevant histogram. The largest measurement of latitude of each individual plaque was used to determine plaque latitude. The sum was used to calculate the mean plaque latitude \pm SEM. Representative immunofluorescence pictures of EHV1-induced plaques in the intermedial nasal septum are shown for neurovirulent or non-neurovirulent EHV1 for each dpi. BM: basement membrane, objective 20x, NI: non-infected epithelial cells.

\section{Figure 4. Quantification and identification of single EHV1-infected cells in different} zones of the intermedial nasal septum for neurovirulent and non-neurovirulent strains. Every tenth section of a serially sectioned block of tissue was collected. Ten sections were analysed for each cell marker separately, giving a total number of 30 sections. The total number of infected cells present in the intermedial nasal septum per zone and per day, is shown in the upper right table. The results for the identification of single infected cells are shown in the lower graphs and are represented as the mean of ten sections \pm SEM. ROI: region of interest.

\section{Figure 5. Quantification and identification of single EHV1-infected cells in different} zones of the nasopharynx for neurovirulent and non-neurovirulent strains. Every tenth section of a serially sectioned block of tissue was collected. Ten sections were analysed for each cell marker separately, giving a total number of 30 sections. The total number of infected cells present in the nasopharynx per zone and per day, is shown in the upper right table. The 
results for the identification of single infected cells are shown in the lower graphs and are represented as the mean of ten sections \pm SEM. ROI: region of interest.

Figure 6. Quantification and identification of single EHV1-infected cells in different zones of the tubal and nasopharyngeal tonsils for neurovirulent and non-neurovirulent strains. Every tenth section of a serially sectioned block of tissue was collected. Ten sections were analysed for each cell marker separately, giving a total number of 30 sections. The total number of infected cells present in the tubal and nasopharyngeal tonsils per zone and per day, is shown in the upper right table. The results for the identification of single infected cells are shown in the lower graphs and are represented as the mean of ten sections \pm SEM. ROI: region of interest.

\section{Figure 7. Quantification and identification of single EHV1-infected cells in different} zones of the mandibular lymph node for neurovirulent and non-neurovirulent strains.

Every tenth section of a serially sectioned block of tissue was collected. Ten sections were analysed for each cell marker separately, giving a total number of 30 sections. The total number of infected cells present in the mandibular lymph node per zone and per day, is shown in the upper right table. The results for the identification of single infected cells are shown in the lower graphs and are represented as the mean of ten sections \pm SEM. ROI: region of interest.

\section{Figure 8. Quantification of viremia for neurovirulent and non-neurovirulent strains.} Ponies were inoculated with a neurovirulent or a non-neurovirulent strain of EHV1. At 0, 1, 2, 3, 4, 5 and 7 days post inoculation (dpi), blood samples were collected and cocultivation of PBMC was performed as mentioned in materials and methods. 
Table I. Percentage of marker positive EHV1-infected individual cells in different tissues of the upper respiratory tract

\begin{tabular}{|c|c|c|c|c|c|c|}
\hline \multirow[t]{3}{*}{ Region of interest } & \multicolumn{6}{|c|}{ Percentage of marker positive EHV1-infected individual cells } \\
\hline & \multicolumn{3}{|c|}{ Neurovirulent strain } & \multicolumn{3}{|c|}{ Non-neurovirulent strain } \\
\hline & $\mathrm{CD} 172 \mathrm{a}^{+}$ & $\mathrm{CD}^{+}$ & $\operatorname{IgM}^{+}$ & $\mathrm{CD} 172 \mathrm{a}^{+}$ & $\mathrm{CD}^{+}$ & $\operatorname{IgM}^{+}$ \\
\hline Nasal septum & $53.4 \pm 22,8$ & $16.2 \pm 11.7$ & $0.3 \pm 0.8$ & $43.9 \pm 12.8$ & $23.6 \pm 8.6$ & 0 \\
\hline Nasopharynx & $69.5 \pm 20.7$ & 0 & $8.3 \pm 20.4$ & $37.9 \pm 35.5$ & $13.6 \pm 5.7$ & $1.1 \pm 2.7$ \\
\hline Tubal and nasopharyngeal tonsils & $66.4 \pm 20.7$ & $11.2 \pm 12.8$ & $4.8 \pm 5.6$ & $28.7 \pm 3.6$ & $21.2 \pm 5.9$ & $0.5 \pm 1.0$ \\
\hline Mandibular lymph nodes & $71.3 \pm 17.9$ & $7.3 \pm 9.5$ & $8.3 \pm 8.8$ & $42.6 \pm 21$ & $26.7 \pm 5.7$ & $7.7 \pm 10.8$ \\
\hline
\end{tabular}




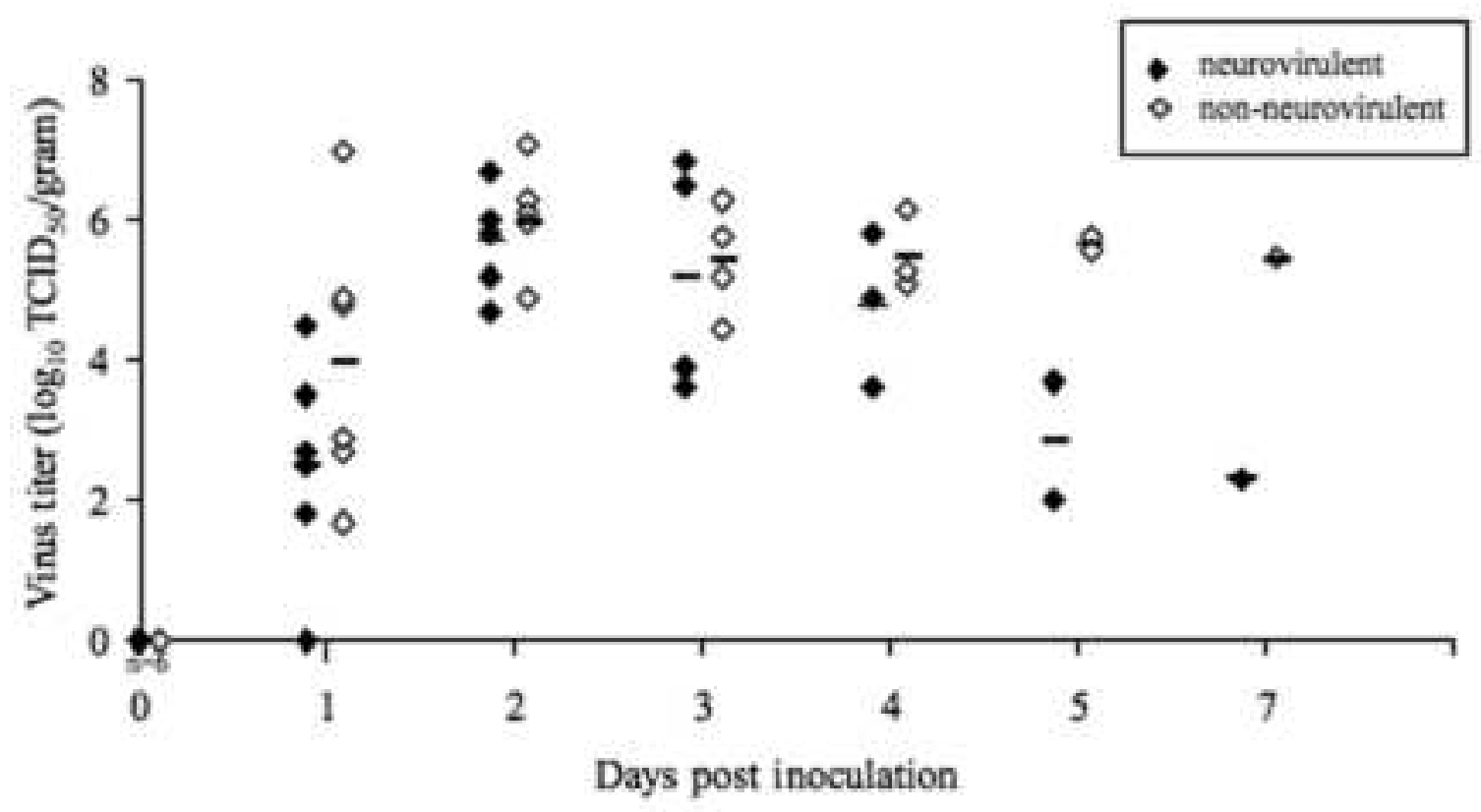

Fig 1 Gryspeerdt et al.

- neurovirulent

- non-neurovinulen

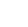




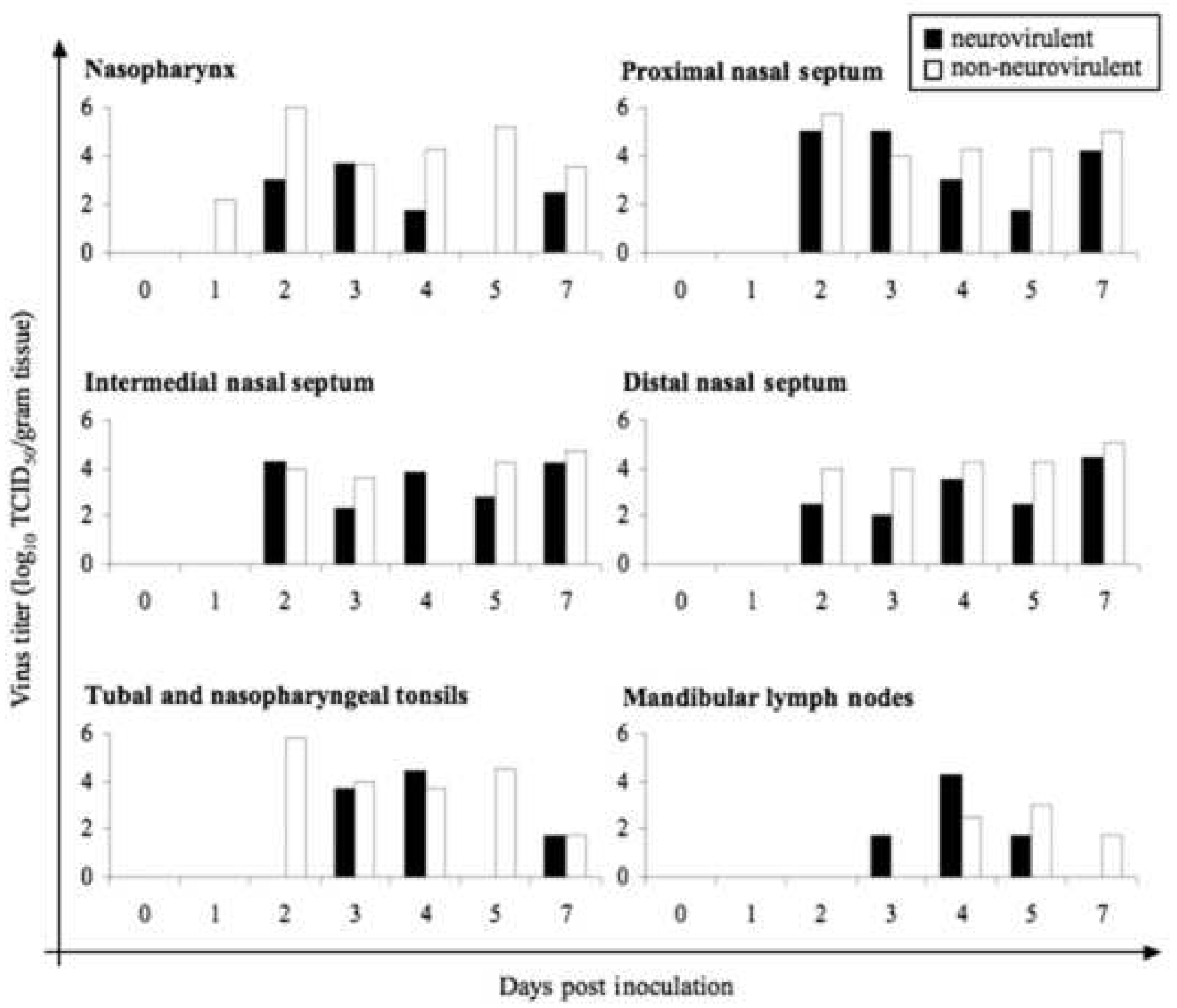

Fig 2 Gryspeerdt $e t$ al. 

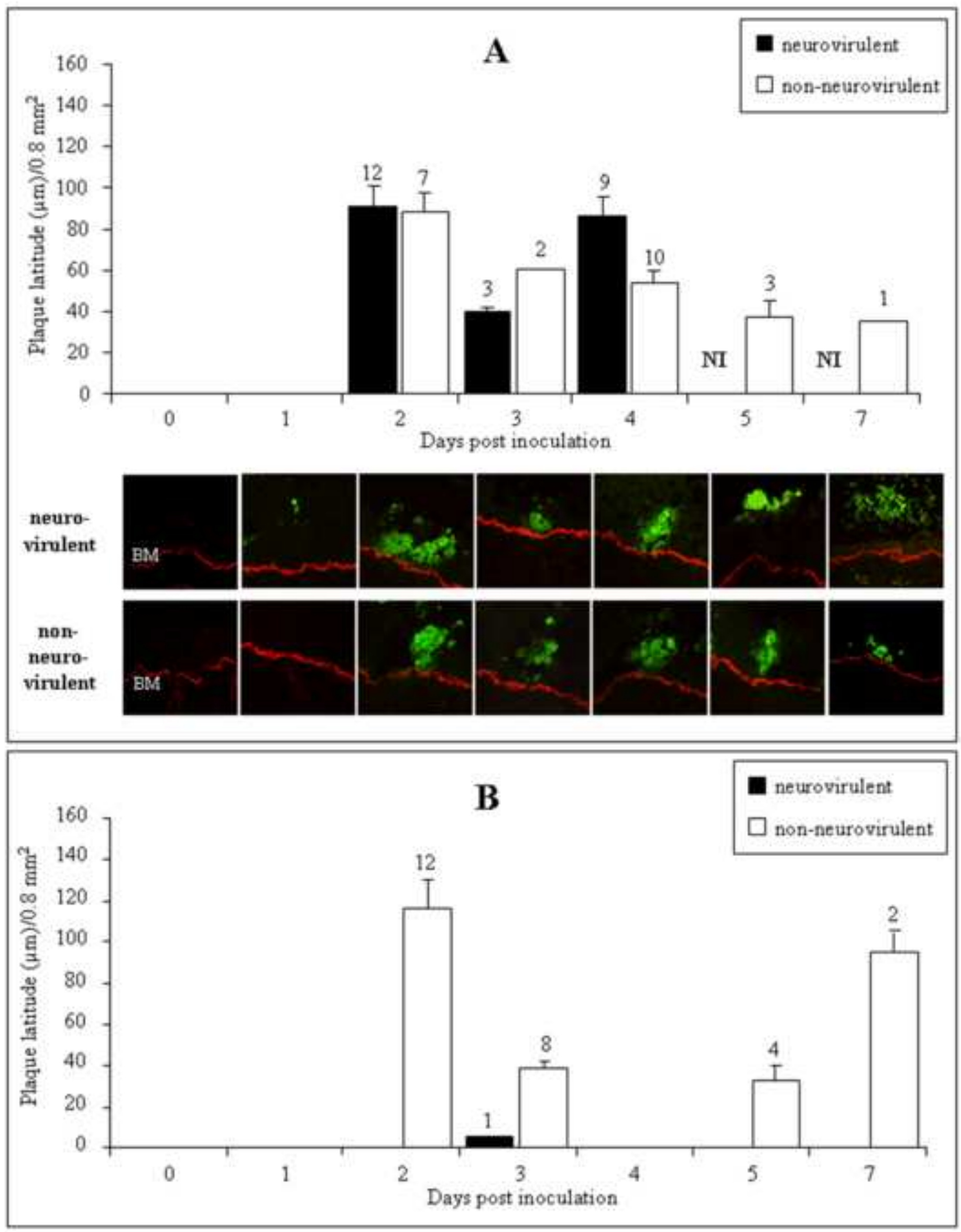

Fig 3 Gryspe erdt et al. 
Schematic overview of the structure of the nasal septum and different counting regions

\begin{tabular}{|c|c|c|c|c|c|c|c|c|}
\hline \multirow[t]{2}{*}{ Strain } & \multirow[t]{2}{*}{ Roi } & \multicolumn{7}{|c|}{$\begin{array}{l}\text { Total number of single infected cells } \\
\text { present at ... dpi } / 30 \text { sections }\end{array}$} \\
\hline & & 0 & 1 & 2 & 3 & 4 & & 7 \\
\hline \multirow[t]{6}{*}{ Neurovirulent } & A & - & 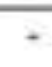 & 34 & 17 & 34 & 137 & 82 \\
\hline & B & $=$ & - & 52 & 13 & 62 & 8 & 60 \\
\hline & $\mathrm{C}$ & - & - & 24 & 8 & 40 & 4 & 18 \\
\hline & D & 0 & 3 & 24 & 34 & 62 & 11 & 9 \\
\hline & $\mathbf{E}$ & 0 & 0 & 24 & 10 & 58 & 11 & 5 \\
\hline & $\mathbf{F}$ & 0 & 0 & 28 & 9 & 22 & 8 & 2 \\
\hline \multirow{6}{*}{$\begin{array}{l}\text { Non- } \\
\text { neurovirulent }\end{array}$} & A & - & - & 3 & 0 & 4 & 1 & 0 \\
\hline & B & $\cdot$ & - & 4 & 3 & 15 & 0 & 0 \\
\hline & $\mathrm{C}$ & - & - & 0 & 1 & 0 & 0 & 0 \\
\hline & D & 0 & 0 & 6 & 0 & 19 & 8 & 0 \\
\hline & $\mathbf{E}$ & 0 & 0 & 0 & 0 & 17 & 6 & 0 \\
\hline & $\mathbf{F}$ & 0 & 0 & 0 & 0 & 25 & 3 & 0 \\
\hline
\end{tabular}

a. epithelium; b: connective tissue; c: glands; d. blood vessel
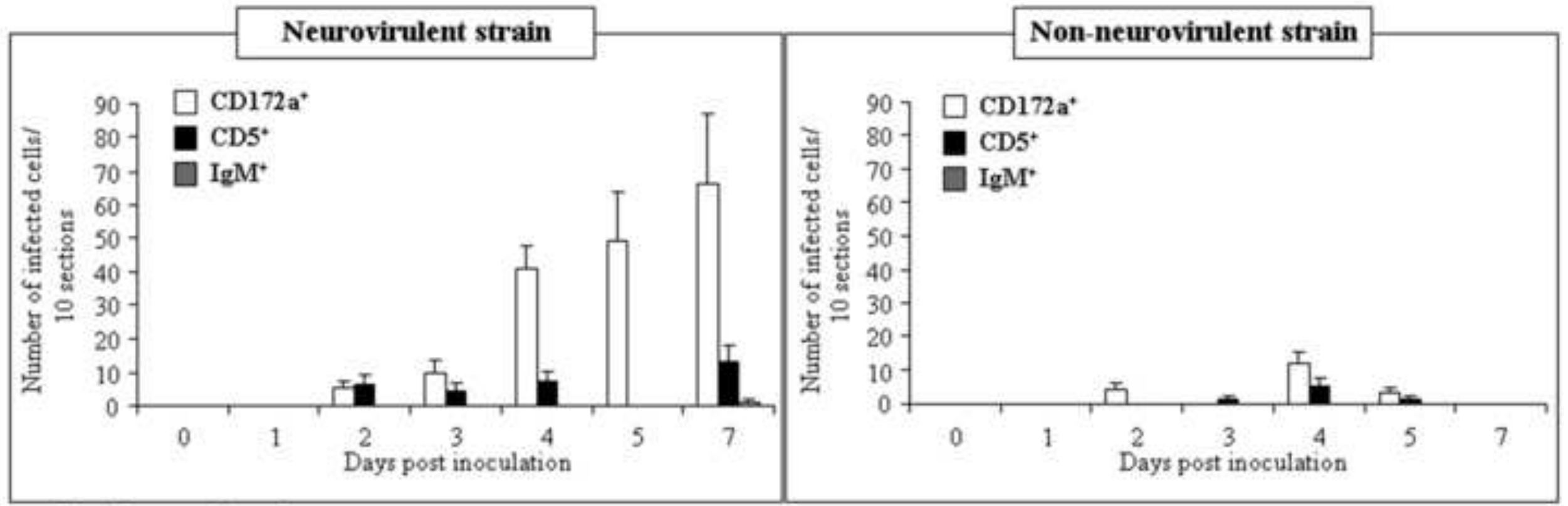

Fig 4 Gryspeerdt et al. 
Schematic overview of the structure of the nasopharynx and different counting regions

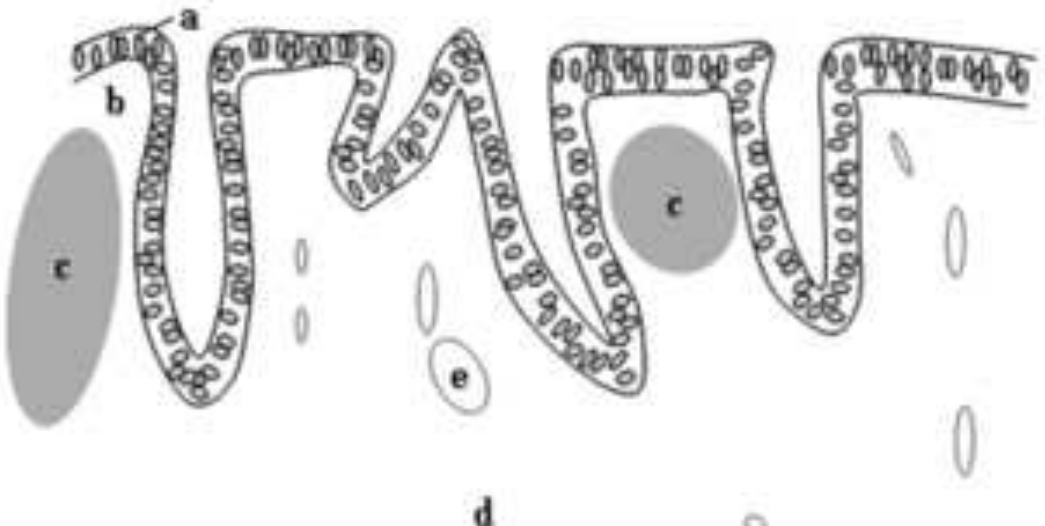

a: epithelium; b: connective tissue; c: lymphocyte aggregate; $d$ : deeper connective tissue; $e$ : blood vessels
Strain Roi Total number of single infected cells present at ... dpi 30 sections

\begin{tabular}{cllllllll} 
& & $\mathbf{0}$ & $\mathbf{1}$ & $\mathbf{2}$ & $\mathbf{3}$ & $\mathbf{4}$ & $\mathbf{5}$ & $\mathbf{7}$ \\
\hline Neurovirulent & a & 0 & 3 & 3 & 7 & 2 & 0 & 1 \\
& b & 0 & 22 & 24 & 118 & 22 & 18 & 23 \\
& c & 0 & 0 & 0 & 0 & 0 & 0 & 0 \\
& d & 0 & 0 & 0 & 0 & 0 & 0 & 0 \\
& e & 0 & 0 & 0 & 0 & 0 & 0 & 0 \\
\hline Non- & a & 0 & 0 & 0 & 0 & 0 & 0 & 0 \\
neurovirulent & b & 0 & 1 & 320 & 15 & 28 & 18 & 1 \\
& c & 0 & 0 & 0 & 0 & 99 & 16 & 1 \\
& d & 0 & 0 & 0 & 0 & 0 & 0 & 0 \\
& e & 0 & 0 & 0 & 0 & 0 & 1 & 0
\end{tabular}
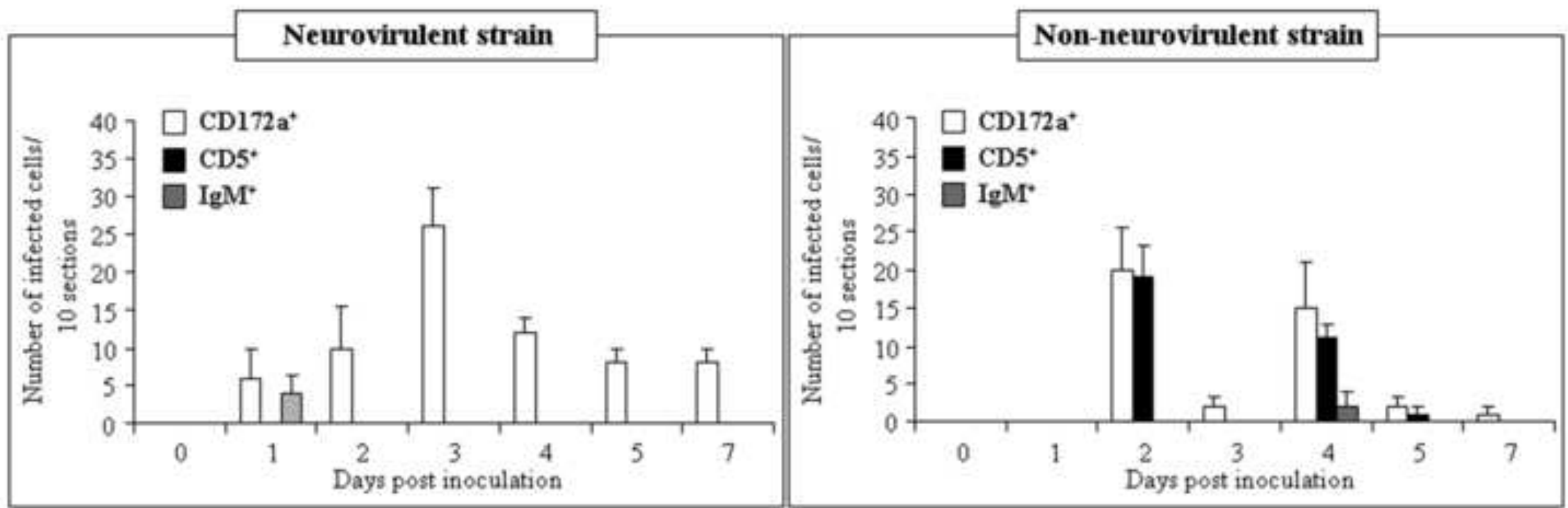

Fig 5 Gryspeerdt et al. 
Schematic overview of the structure of tubal and nasopharyngeal tonsils and different counting regions

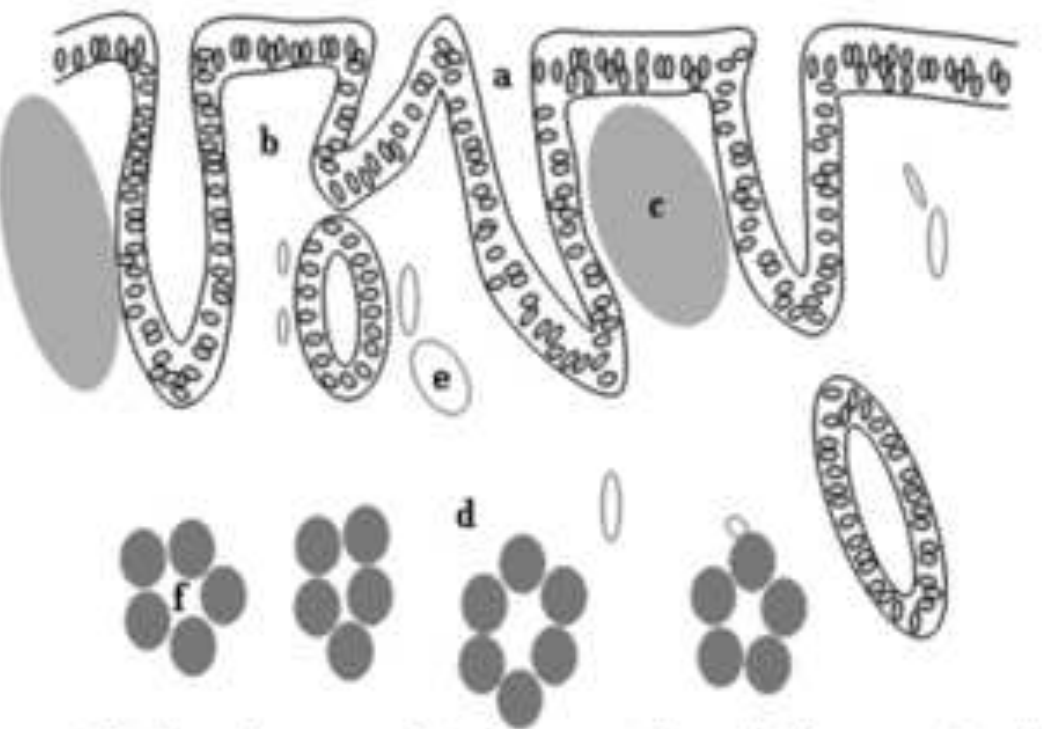

a: epithelium; b: connective tissue; $\mathrm{c}$ : lymphoid aggregate; $d$ :

\begin{tabular}{ccccccccc}
\hline Strain & Roi & \multicolumn{7}{c}{ Total number of single infected cells } \\
& & $\mathbf{0}$ & $\mathbf{1}$ & $\mathbf{2}$ & $\mathbf{3}$ & $\mathbf{4}$ & $\mathbf{5}$ & $\mathbf{7}$ \\
\hline Neurovirulent & a & 0 & 0 & 5 & 77 & 95 & 0 & 14 \\
& b & 0 & 0 & 6 & 273 & 538 & 1 & 51 \\
& c & 0 & 0 & 3 & 260 & 241 & 2 & 0 \\
& d & 0 & 0 & 0 & 86 & 150 & 2 & 7 \\
& e & 0 & 0 & 0 & 133 & 85 & 0 & 2 \\
& f & 0 & 0 & 0 & 38 & 117 & 1 & 13 \\
\hline Non- & a & 0 & 0 & 7 & 23 & 7 & 18 & 5 \\
neurovirulent & b & 0 & 0 & 39 & 173 & 51 & 50 & 2 \\
& c & 0 & 0 & 10 & 34 & 31 & 487 & 8 \\
& d & 0 & 0 & 44 & 78 & 14 & 8 & 2 \\
& e & 0 & 0 & 0 & 5 & 3 & 0 & 2 \\
& f & 0 & 0 & 2 & 0 & 2 & 4 & 13 \\
\hline
\end{tabular}

deeper connective tissue; e: blood vessel; f glands
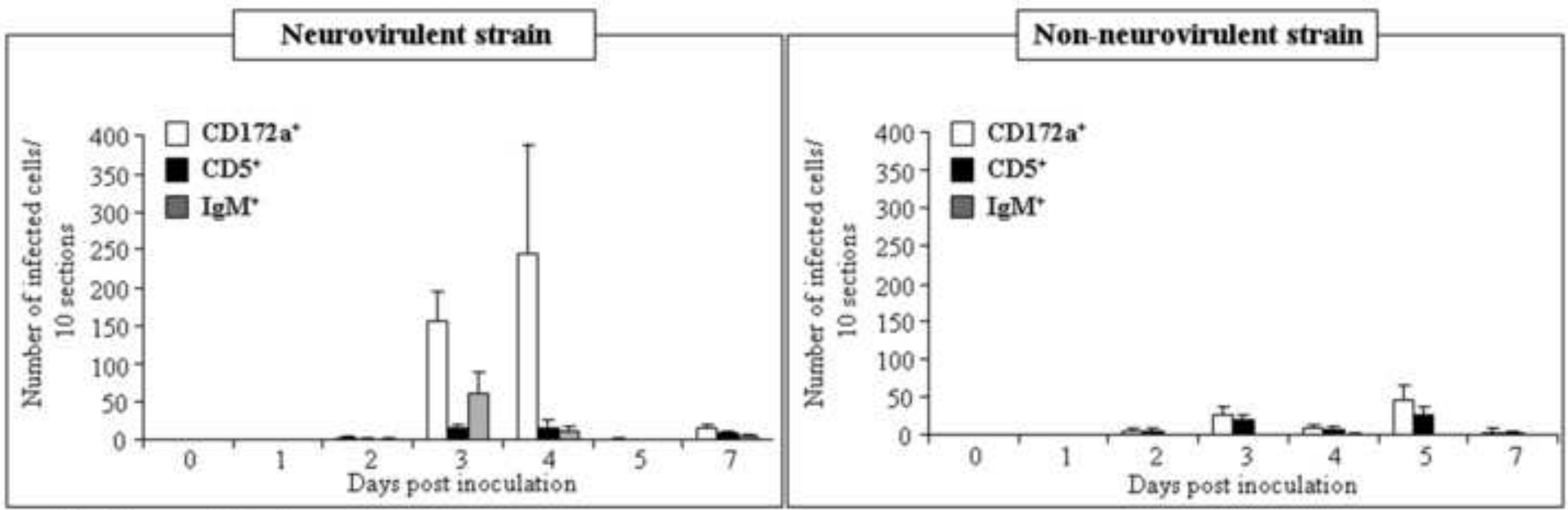

Fig 6 Gryspeerdt et al. 
Schematic overview of the structure of the mandibular lymph node and different counting

regions

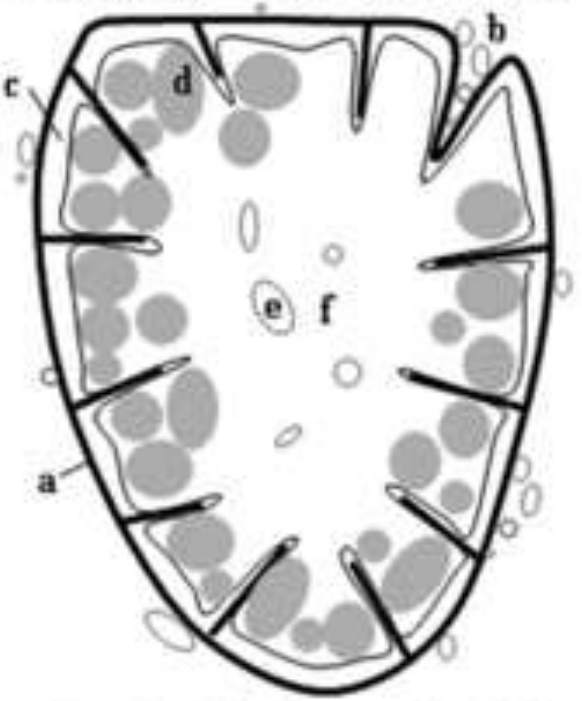

a: capsule and trabecula; $b$ : vessels of the capsule; $c$ : marginal sinus; d; cortical nodule; e: vessels in medulla;

f. medulla

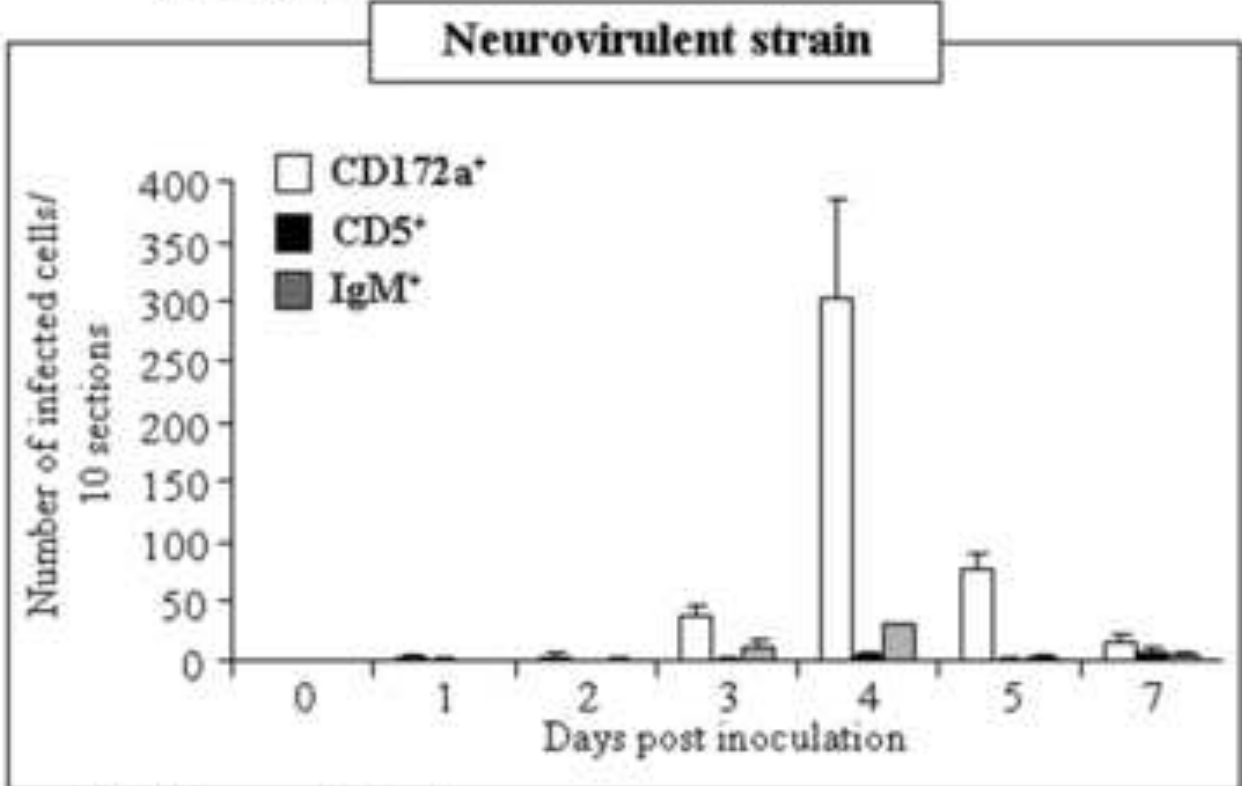

Fig 7 Gryspeerdt et al.

\begin{tabular}{|c|c|c|c|c|c|c|c|c|}
\hline \multirow[t]{2}{*}{ Strain } & \multirow[t]{2}{*}{ Roi } & \multicolumn{7}{|c|}{$\begin{array}{l}\text { Total number of single infected cells } \\
\text { present at ... dpi } / 30 \text { sections }\end{array}$} \\
\hline & & 0 & 1 & 2 & 3 & 4 & 5 & 7 \\
\hline \multirow[t]{6}{*}{ Neurovirulent } & a & 0 & 0 & 0 & 40 & 10 & 162 & 1 \\
\hline & b & 0 & 12 & 2 & 16 & 40 & 12 & 0 \\
\hline & c & 0 & 17 & 6 & 106 & 846 & 170 & 34 \\
\hline & d & 0 & 2 & 2 & 31 & 36 & 4 & 19 \\
\hline & e & 0 & 0 & 0 & 3 & 1 & 0 & 0 \\
\hline & f & 0 & 0 & 9 & 49 & 70 & 14 & 39 \\
\hline \multirow{6}{*}{$\begin{array}{l}\text { Non- } \\
\text { neurovirulent }\end{array}$} & a & 0 & 0 & 0 & 0 & 4 & 5 & 1 \\
\hline & b & 0 & 0 & 0 & 0 & 0 & 0 & 0 \\
\hline & c & 0 & 1 & 2 & 4 & 40 & 39 & 1 \\
\hline & d & 0 & 0 & 0 & 0 & 5 & 17 & 8 \\
\hline & e & 0 & 0 & 0 & 0 & 0 & 0 & 0 \\
\hline & f & 0 & 0 & 0 & 0 & 41 & 82 & 1 \\
\hline
\end{tabular}

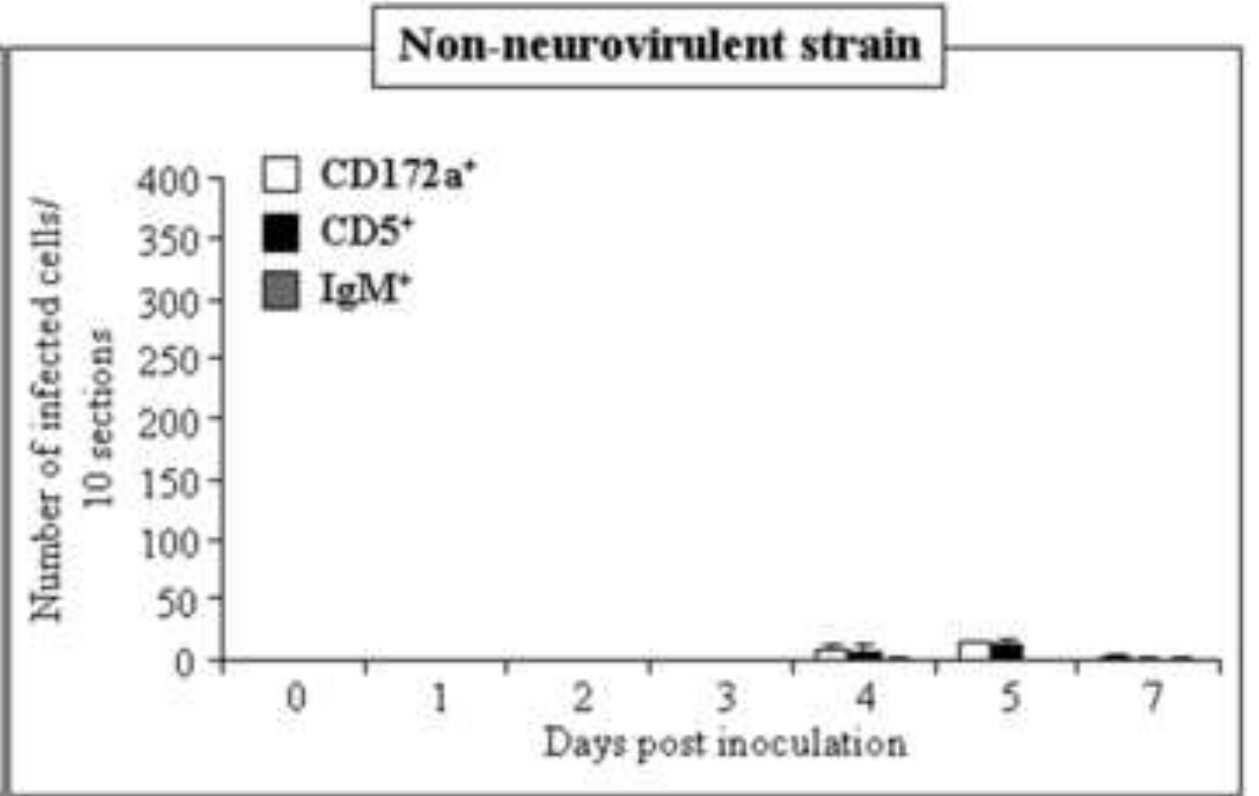

Fraperdi et al.

Hage si or 38 


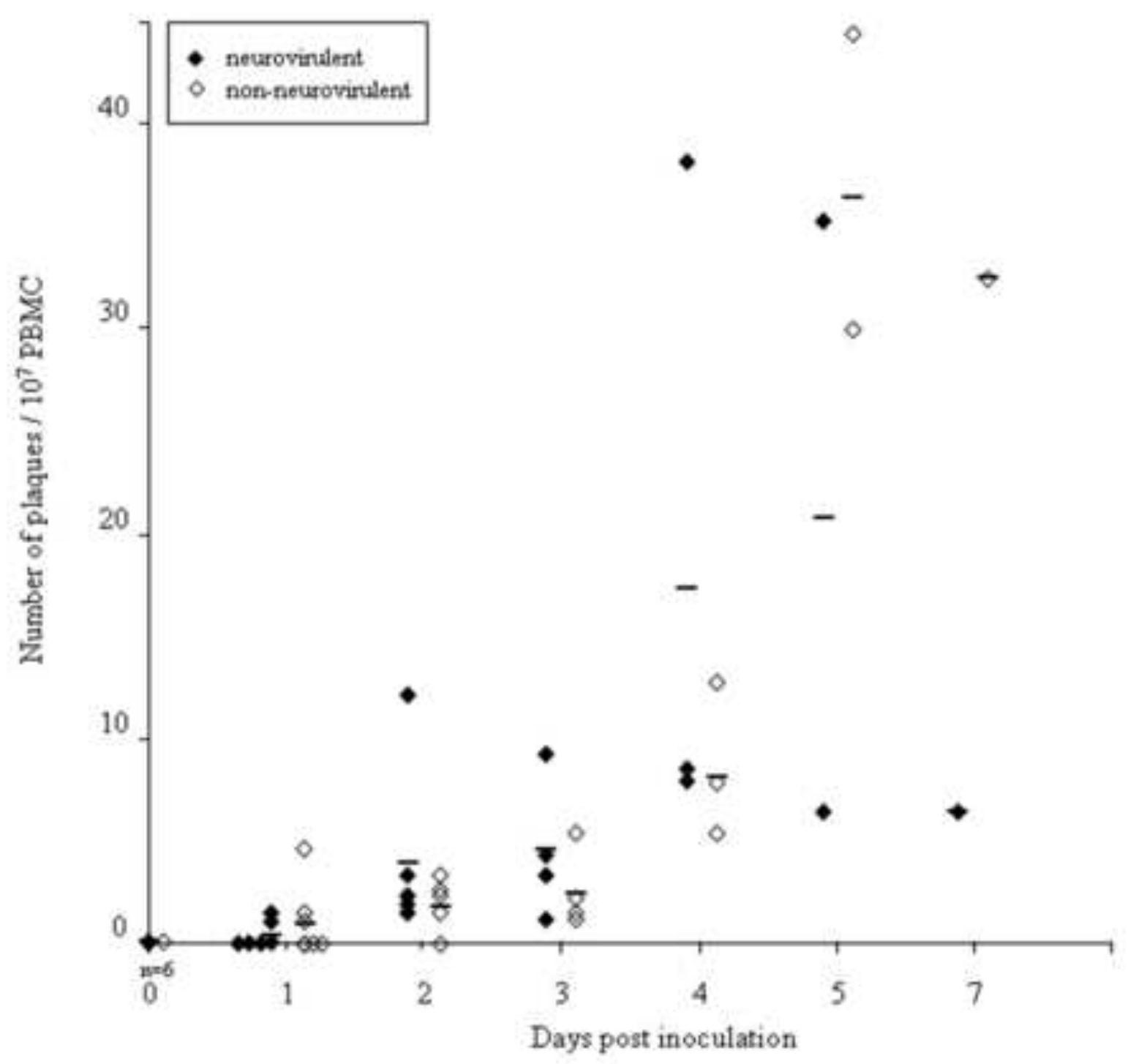

Fig 8 Gryspeerdt et al.

.
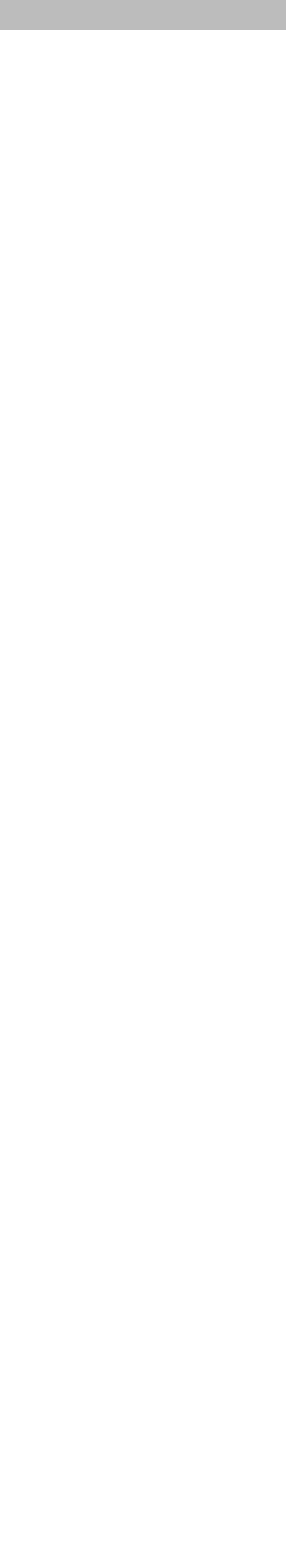

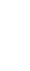

Days post inoculation

(1) 